\title{
Key Plant, Key Pests: Oak (Quercus spp.) $)^{1}$
}

\author{
Juanita Popenoe, Caroline R. Warwick, Adam G. Dale, and Alfred Huo ${ }^{2}$
}

\section{Key Plant: Oak (Quercus spp.)}

Southern live oaks (Quercus virginiana) are a staple tree of the southeastern United States, especially Florida. There are 19 oak species native to Florida, which can be divided into two large groups, white oaks and red oaks. Most are deciduous, with only a few being evergreen. They tend to grow relatively fast. Oaks naturally occur across various ecosystems; some are more adapted to hydric (wet) sites, while others can withstand xeric (dry) soils. Mature oak tree height can range from 30 to 90 feet, depending on the species. The bark is generally coarse and dense, although there is variability among oak species. Oaks provide many benefits to wildlife due to their large canopies and seeds. They are also highly valued as ornamental plants due to their shade and aesthetic qualities as well as their ability to tolerate a variety of stress factors commonly associated with urban and residential landscapes. Oaks are among the most diverse and widely distributed and planted tree genera, with members of Quercus found in every USDA Hardiness Zone and throughout North America (Gilman and Watson 2014). Similarly, oaks support a high level of biodiversity, making them an extremely valuable component of our native ecosystems (Tovar-Sanchez 2009).

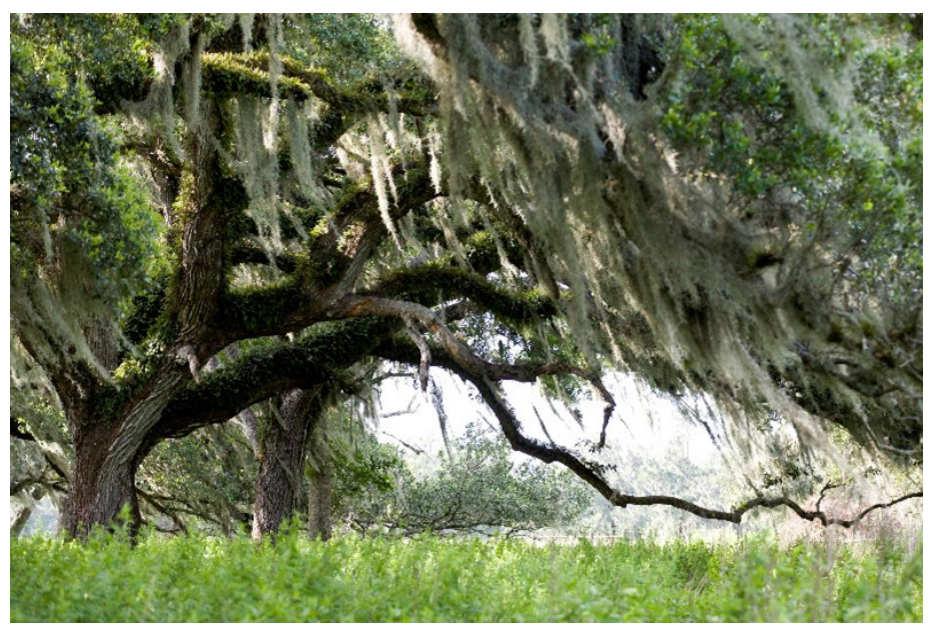

Figure 1. An oak tree in a pasture.

Credits: Tyler Jones, UF/IFAS

\section{Key Pests: Oak (Quercus spp.)}

This series of Key Plant, Key Pests publications is designed for Florida gardeners, horticulturalists, and landscape professionals to help identify common pests associated with common Florida flora.

This publication provides information and general management recommendations for insect borers, caterpillars, insect-induced galls, twig girdlers, oak leaf blister, root and butt rot, Tubakia leaf spot, mistletoe, psocids, lace bugs, woolly aphids, powdery mildew, Spanish and ball moss, and lichens. For a more comprehensive guide of woody

1. This document is ENH1332, one of a series of the Environmental Horticulture Department, UF/IFAS Extension. Original publication date December 2020. Visit the EDIS website at https://edis.ifas.ufl.edu for the currently supported version of this publication.

2. Juanita Popenoe, multicounty commercial fruit production agent IV, UF/IFAS Extension Lake County; Caroline R. Warwick, science communication specialist; Adam G. Dale, assistant professor, Department of Entomology and Nematology; and Alfred Huo, assistant professor, Environmental Horticulture Department, UF/IFAS Mid-Florida Research and Education Center; UF/IFAS Extension, Gainesville, FL 32611.

All chemicals should be used in accordance with directions on the manufacturer's label.

The Institute of Food and Agricultural Sciences (IFAS) is an Equal Opportunity Institution authorized to provide research, educational information and other services

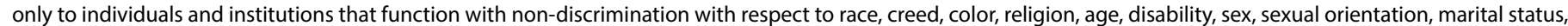

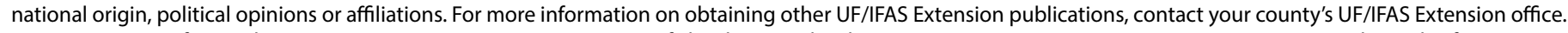
U.S. Department of Agriculture, UF/IFAS Extension Service, University of Florida, IFAS, Florida A \& M University Cooperative Extension Program, and Boards of County Commissioners Cooperating. Nick T. Place, dean for UF/IFAS Extension. 
ornamental insect management, download the current Professional Disease Management Guide for Ornamental Plants, the Integrated Pest Management in the Commercial Ornamental Nursery guide, or the Southeastern US Pest Control Guide for Nursery Crops and Landscape Plantings.

\section{Borers}

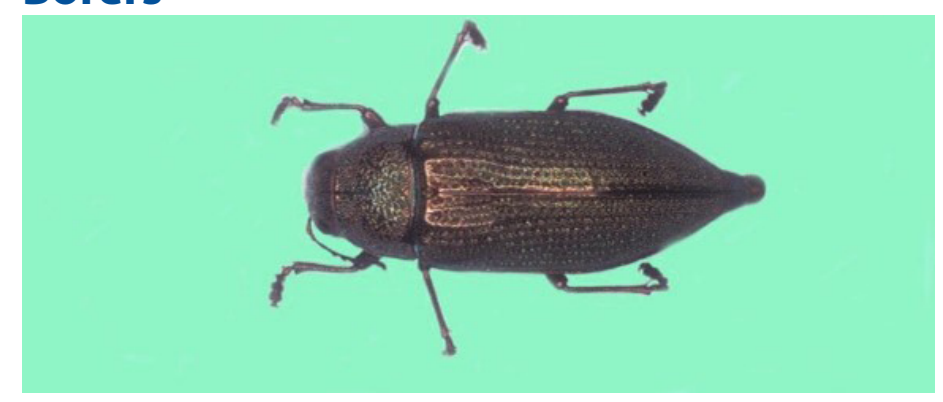

Figure 2. This metallic wood borer beetle is a common oak pest. Credits: J. Castner, UF/IFAS

\section{RECOGNITION}

Insect borers include many species of beetles, moths, and wasps that tunnel into the trunk and branches of trees, where they feed and reproduce within the woody tissue. There are several different borers that attack oaks, including flathead borers (Buprestid "jewel" beetles), roundhead borers (Cerambycid "long-horned" beetles), ambrosia beetles, clearwing moths, and carpenter worms. Although they are typically concealed within the woody tissue, borers can be detected by searching for characteristic holes in the trunk and sawdust, sap staining, or excrement around them or at the base of the tree. Attacked trees may also show symptoms such as foliage discoloration, wilting, or branch dieback. By carefully removing the bark around the borer holes, you may see the tunneling caused by the insects and may find the insects themselves. In most cases, the symptoms remain even after the insects exit the tree.

\section{CONTRIBUTING FACTORS}

In most cases, borers attack trees that are under environmental stress or attack from other pests. Among the most common causes of stress-induced borer attack is too much or too little water. Trees affected are generally weakened or wounded by some other predisposing factor such as root rot, soil disturbance, or physical injuries to their trunk or branches.

\section{MANAGEMENT RECOMMENDATIONS}

To avoid infestations, keep trees healthy. Remove and destroy severely infested trees, and prune out dead and dying branches. Once infested, little can be done to reverse damage or remove established borers. Minimal relief can be achieved by temporarily protecting other nearby trees with approved insecticides applied to the trunk from spring to fall, depending on the target pest. More information about borers can be found in Native and Exotic Insect Borers Are Important Crop Pests in the U.S. (Frank and Mizell 2006).

\section{Caterpillars}

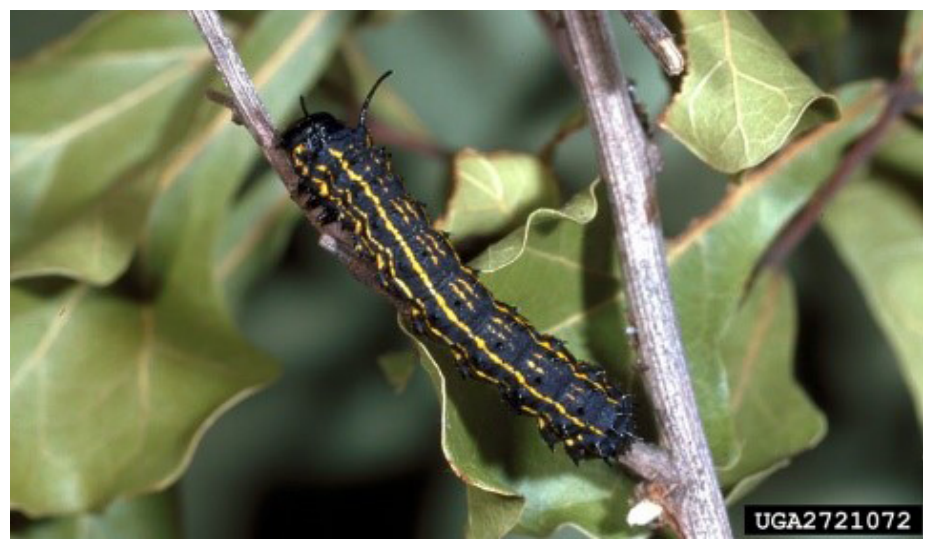

Figure 3. An orangestriped oakworm (Anisota senatoria) caterpillar on oak. This species can be a nuisance pest in residential neighborhoods, defoliating laurel and water oaks and depositing frass in and around swimming pools.

Credits: Paul M. Choate, UF/IFAS

\section{RECOGNITION}

Caterpillars are the larvae of moths and butterflies. Oak trees support a vast diversity of moth and butterfly species. Several of these species attack oaks and can be occasional pests, including the eastern tent caterpillar (Malacosoma americanum), forest tent caterpillar (Malacosoma disstria Hübner), yellownecked caterpillar (Datana ministra (Drury)), fall webworm, yellowstriped oakworm (Anisota peigleri Riotte), orangestriped oakworm (Anisota senatoria), pinkstriped oakworm (Anisota virginiensis), multiple tussock moth species, and leafroller moths. Look for caterpillars hanging from silk strands, grouped in webs, crawling on tree trunks, or on other plant material under the oaks. Frass pellets or caterpillar excrement on surfaces underneath trees may be conspicuous. Caterpillars feed on the leaves, causing holes or jagged edges in leaves. Large numbers of caterpillars may cause complete defoliation. Eastern tent caterpillars make webs in the crotches (forks) of branches, while fall webworms create webs at the tips of branches. Other types of caterpillars may be identified by color patterns and by unique tufts of hairs. Many species have one generation per year, while others may have two to four.

\section{CONTRIBUTING FACTORS}

Caterpillar infestation levels vary from year to year. Natural predators (birds, various insects and spiders), parasites (many wasps and flies), and weather conditions usually 
keep populations below damaging levels. Outbreaks do occur but usually subside after one to two years.

\section{MANAGEMENT RECOMMENDATIONS}

After identifying the species, determine its life cycle, seasonality, and what management practices may affect its success. In severe cases, use of an approved insecticide may be warranted. Insecticide application to oaks, particularly large trees, requires training and should be done by a professional in most cases.

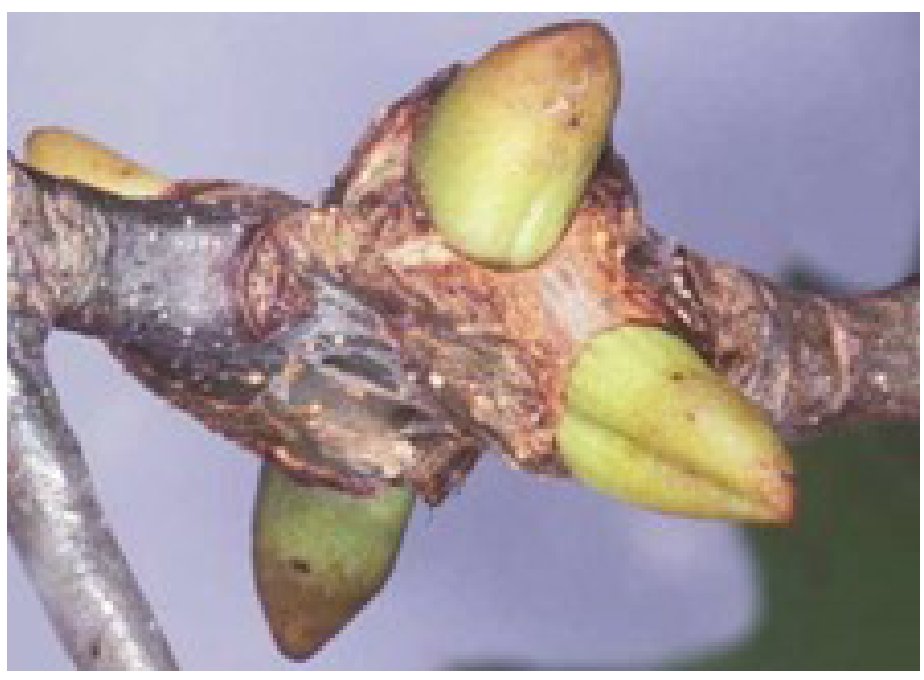

Figure 4. Mature spine-bearing potato gall caused by the gall wasp, Callirhytis quercusclaviger (Ashmead), looks like strange buds. Credits: Lyle J. Buss, UF/IFAS

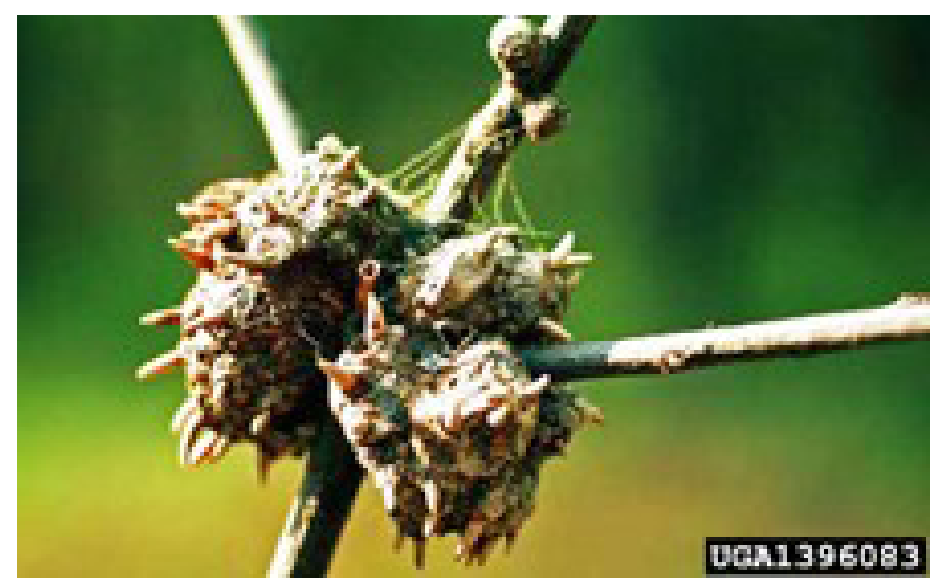

Figure 5. Mature horned oak galls caused by the gall wasp, Callirhytis cornigera (Osten Sacken).

Credits: USDA Forest Service, www.forestryimages.org

\section{Insect-Induced Galls RECOGNITION}

Galls are malformed plant tissue that forms in response to egg-laying or feeding by insects like wasps, midges, mites, aphids, or beetles. Galls occur in many forms, colors, and shapes. They may be hairlike projections, spheres, rosettes, or woody swellings and can occur on leaves, twigs, or branches. Although galls cause aesthetic damage, in most cases they cause little or no damage to the tree. In severe cases, an overabundance of galls can cause branch dieback, crown thinning, and ultimately tree mortality. One type of insect-induced gall in Florida oaks are caused by Cynipid gall wasps (Callirhytis quercusclaviger and Callirhytis cornigera). Small exit holes on the outside of the gall indicate that the insects have already emerged, but the gall remains. Some beneficial organisms live in abandoned galls. Infested trees will continue to support populations of gall insects, and the galls will never go away unless the twigs are removed.

\section{CONTRIBUTING FACTORS}

Little is known about how environmental factors may influence susceptibility to galling insect attack. Callirhytis quercusclaviger particularly favors laurel oaks, while Callirhytis cornigera occurs on water oak as well as other oak species. Insect-induced galls can occur on any oak host. Some cultivars (cultivated varieties) of oaks are more vulnerable to gall attacks than others. For example, 'Cathedral' live oaks are highly susceptible to gall wasp damage, while other cultivars are not.

\section{MANAGEMENT RECOMMENDATIONS}

Little can be done to prevent or control galls. The best approach is to purchase gall-free plants and plants that are known to be resistant or less susceptible to insect-induced galls. Stem and branch galls can be pruned out and destroyed if not on main trunks or branches. In some cases, galls on stems and main branches may have a girdling effect and can result in weak points and possible limb breakage if not removed. Leaf galls are harmless but can be unsightly in some cases.

\section{Twig Girdler}

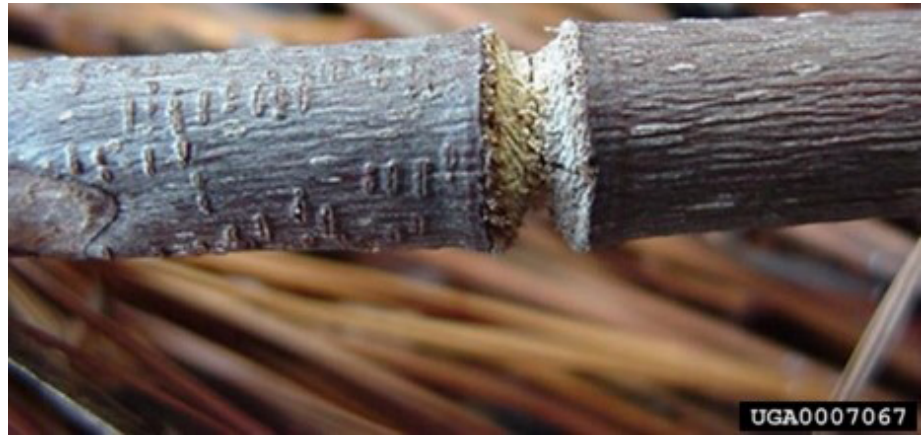

Figure 6. Damage caused by a female twig girdler.

Credits: Herbert A. "Joe" Pase III, Texas A\&M Forest Service, Bugwood. org 


\section{RECOGNITION}

The twig girdler (Oncideres cingulata) is a fairly uncommon gray-brown beetle with long antennae. As the name suggests, this beetle chews away the circumference of twigs, causing them to wilt or die. Twigs will be found hanging in trees or on the ground during the fall. The severed ends of the twigs appear to have been whittled to a dull point.

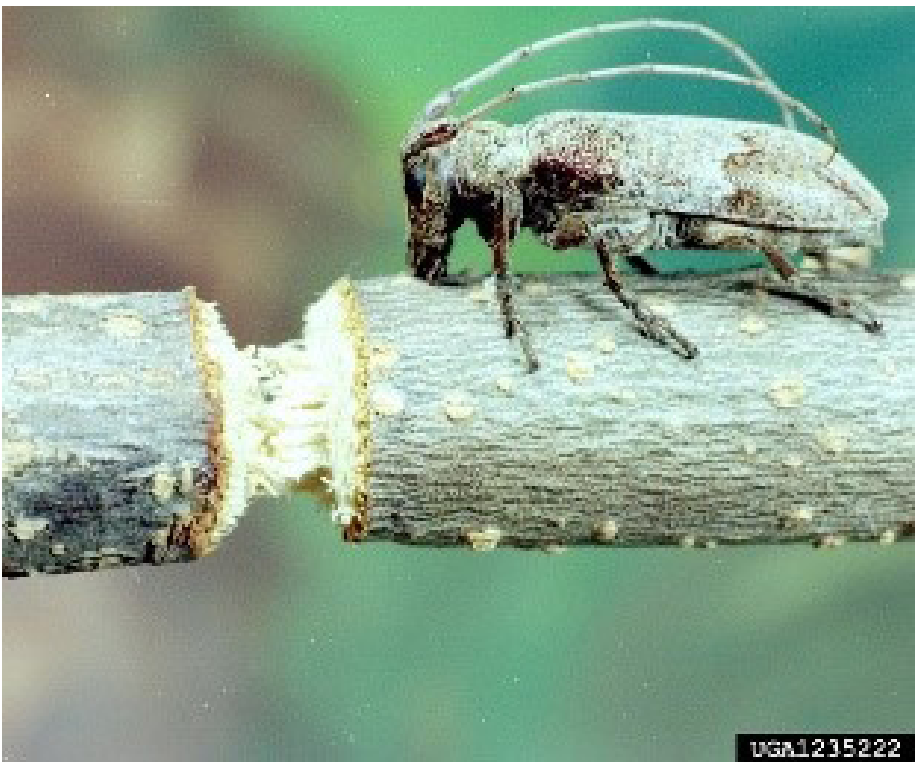

Figure 7. An adult twig girdler on a pecan branch.

Credits: Clemson University-USDA Cooperative Extension Slide Series, Bugwood.org

\section{CONTRIBUTING FACTORS}

Although difficult to control, dry twigs and branches make it easier for the female twig girdler to chew around the bark and lay eggs.

\section{MANAGEMENT RECOMMENDATIONS}

To control this pest, monitor for girdled twigs that are hanging in tree canopies or have fallen to the ground beneath trees during the fall or winter. Collect and destroy any girdled twigs because these contain the immature twig girdlers that will emerge the following year. Infested twigs may be burned, buried in moist soil, or exposed to dry heat to destroy larvae. Insecticidal control is usually not effective because it must be directed at the adults. For more information, visit the 4-H Forest Resources page.

\section{Oak Leaf Blister}

\section{RECOGNITION}

Oak leaf blister (Taphrina caerulescens) is a fungal pathogen that causes raised or wrinkled blisters on newly developed leaves during mild, rainy spring weather. Initially pale green, the blisters will gradually turn brown and die later in the season. The tops of leaves may have brown raised spots, with the underside having sunken spots. Severe infections cause distortion of newly expanding leaves and may cause limited defoliation.

\section{CONTRIBUTING FACTORS}

Prolonged conditions of wet, cool, spring weather promote infection on younger leaves.

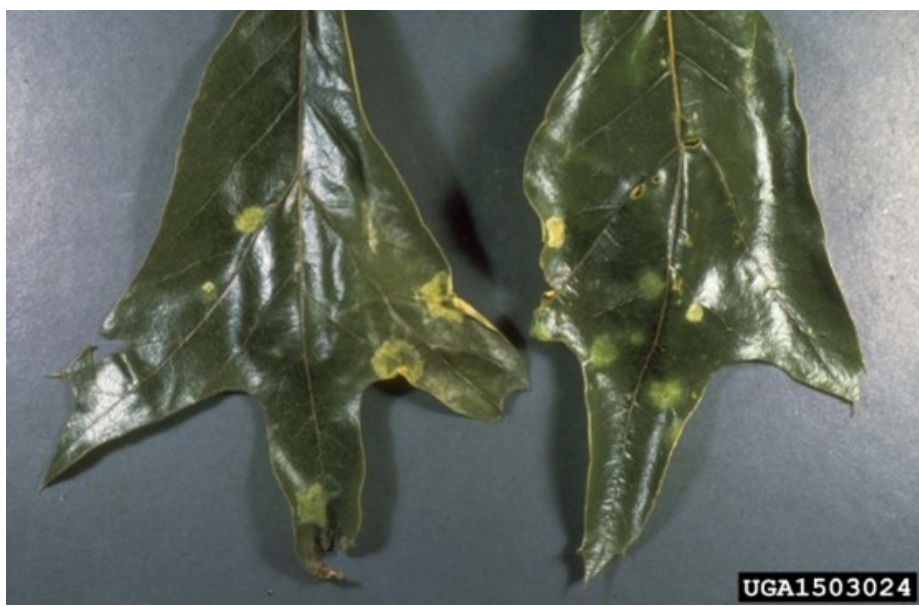

Figure 8. Oak leaf blister spots on southern red oak leaves. Credits: Paul H. Peacher, USDA Forest Service, Bugwood.org

\section{MANAGEMENT RECOMMENDATIONS}

Although oak leaf blister is a surface blemish influenced by weather, fungicides may be used for control in severe cases, especially if a wet season is predicted or there was a previous outbreak in the last year. The most effective time to apply the fungicide for this type of problem is in winter, prior to bud break. If a tree has suffered an outbreak, rake and discard fallen leaves to reduce inoculum for the following year. For more information, visit the $4-\mathrm{H}$ Forest Resources page.

\section{Root and Butt Rots}

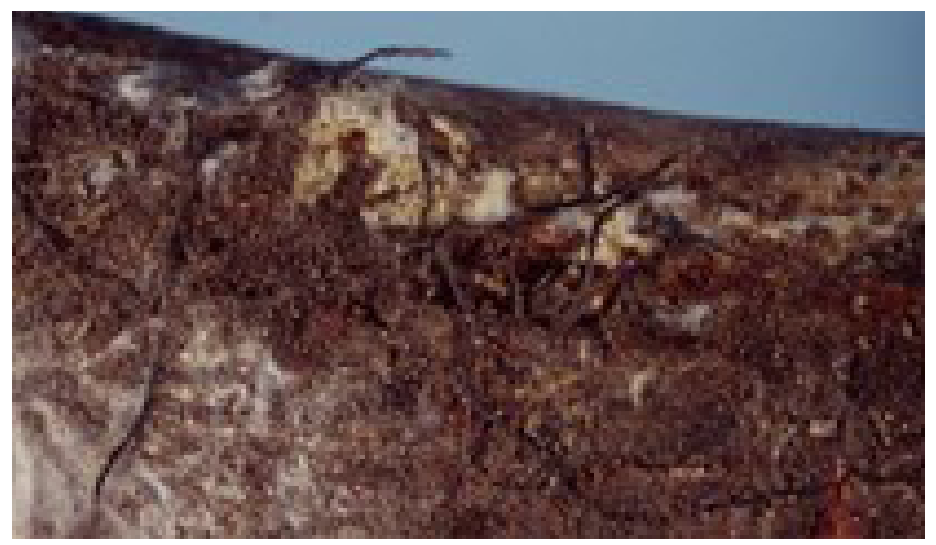

Figure 9. Rhizomorphs of Armillaria spp. produced under the bark of an infected root.

Credits: Ed Barnard, UF/IFAS

\section{RECOGNITION}

Root and butt rots are caused by wood-decaying fungal pathogens that invade woody plant tissue. Aboveground 
symptoms of root and/or butt rots include various degrees of crown dieback, loss or discoloration of foliage, stunted growth, and a generally unhealthy appearance. Internally, roots and trunks may show discoloration, but this is rarely apparent unless branches are pruned off or are damaged during a storm. Fruiting bodies, such as shelf fungi or mushrooms, may be present at or near the base of the tree. Root and butt rots are associated with several fungal pathogen genera, including Armillaria spp., Inonotus dryadeus, Laetiporus spp., and Ganoderma spp.

\section{CONTRIBUTING FACTORS}

Trees that have been injured are susceptible to these diseases. Poor soil conditions, such as compaction or excessive moisture, also favor disease.

\section{MANAGEMENT RECOMMENDATIONS}

Discourage rots by keeping plants healthy with proper planting and establishment. Avoid wounds to trunk and roots, and when transplanting, make sure not to plant too deeply. Remove affected trees in the nursery to reduce spread from spores to other wounds. Consider soil replacement or fumigation if replanting in the same site (Sanagorski, Trulock, and Smith 2016).

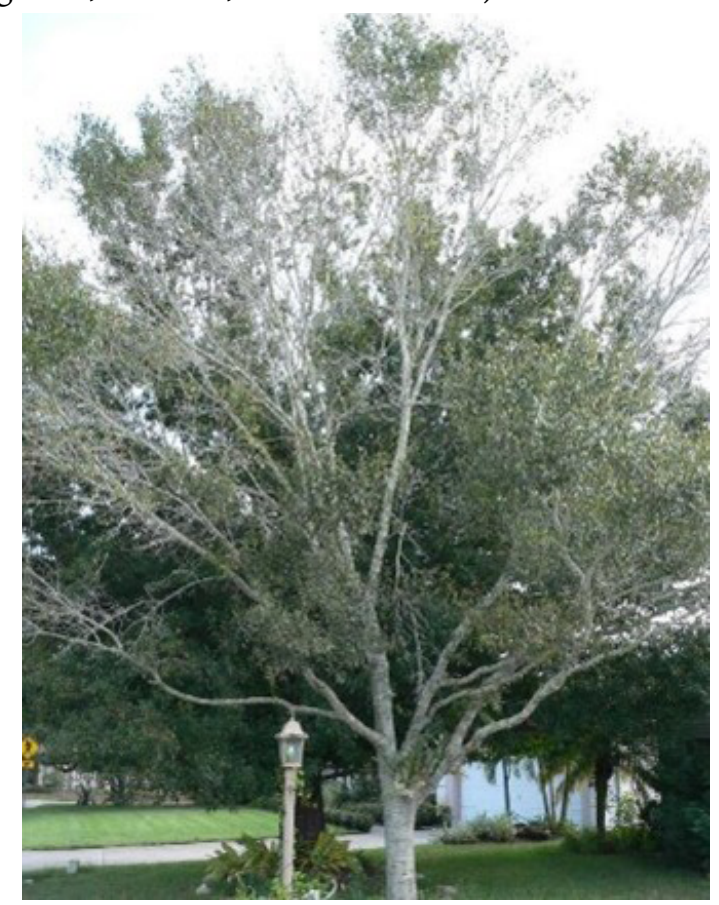

Figure 10. Thinning foliage of a laurel oak (Quercus hemisphaerica) infected with Armillaria tabescens.

Credits: Jason Smith, UF/IFAS

\section{Tubakia Leaf Spot}

\section{RECOGNITION}

Tubakia leaf spot causes small brown leaf spots that may coalesce and cause leaf distortion on new growth. Dark to reddish-brown spots are one-quarter to one-half inch in diameter and are typically surrounded by yellow rings. Severely infected leaves will drop from the plant.

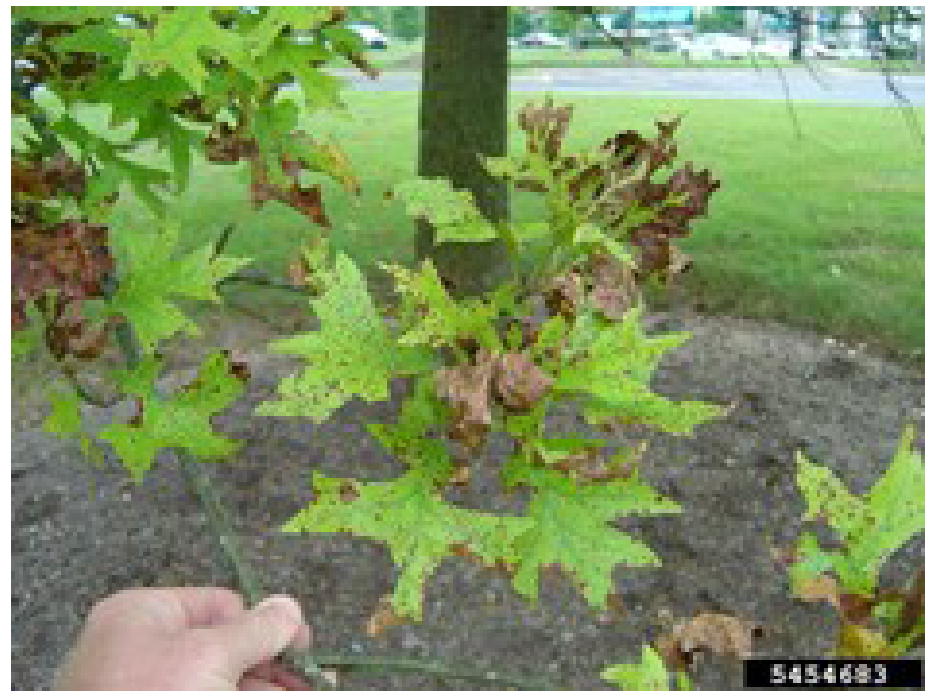

Figure 11. Tubakia leaf spots coalescing on oak leaves.

Credits: Jason Sherman, Vitalitree, Bugwood.org

\section{CONTRIBUTING FACTORS}

This disease is most prevalent on trees in the red oak group, but it can occur on almost any oak species. Frequent overhead irrigation or abundant rainfall favor disease development. This disease is most severe in late summer and early fall. Various stresses, such as transplanting or nutrient deficiencies (especially iron), also encourage disease growth.

\section{MANAGEMENT RECOMMENDATIONS}

Identify stress factors that may be contributing to disease growth, and correct them to minimize stress on the tree. Severely infected leaves should be collected and destroyed to minimize the spread of the disease. Prune established trees to promote air movement and structure. Apply registered fungicides if infection is severe (Ruhl 2018).

\section{Mistletoe (Phorandendron serotinum) RECOGNITION}

Mistletoe is an evergreen parasitic plant that grows in large clumps and is usually noticed when oaks lose their leaves in the fall. Mistletoe becomes attached to the host plant by haustoria (rootlike structures) that take nutrients from the host tree. Mistletoe is most commonly found in laurel oaks in Florida.

\section{CONTRIBUTING FACTORS}

Older trees and trees harmed by pests or storms are more likely to host mistletoe. The white berries, each with a sticky seed, are typically spread by birds from tree to tree. 
Other tree hosts include pecan, hickories, elm, and other hardwoods.

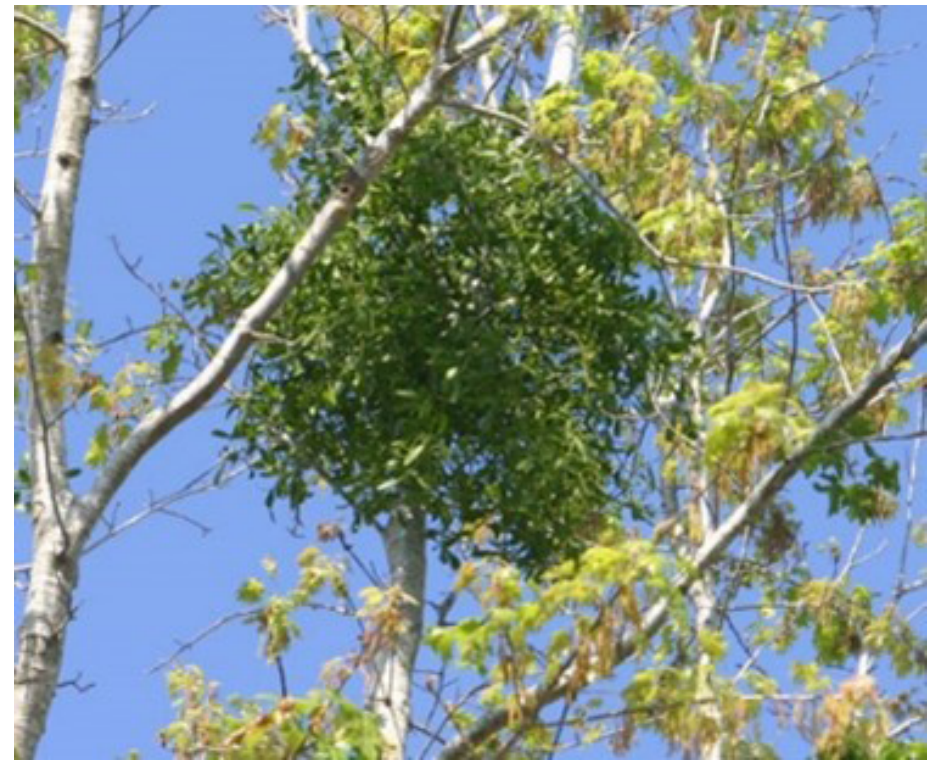

Figure 12. A cluster of mistletoe.

Credits: UF/IFAS Environmental Horticulture (https://hort.ifas.ufl.edu/ woody/mistletoe.shtml)

\section{MANAGEMENT RECOMMENDATIONS}

To control the spread, prune at least 1 foot below where the mistletoe is attached. Hiring a licensed pest control professional or arborist to apply a growth-regulating chemical to the mistletoe during the tree's dormant months may alleviate some problems for infestations that are not easily pruned out. For trees with taller canopies, hiring an arborist to trim back infestations may be necessary (Perry and Elmore 2006).

\section{Psocids}

\section{RECOGNITION}

Psocids (commonly referred to as tree cattle or bark lice) are small insects that actively move in large aggregations (herds) on tree trunks or branches. They may be covered with a fine webbing, which is often the first sign noticed. Psocid individuals are small (about one-quarter inch) and the adults have wings. Psocids are a curiosity, causing no harm to plants but creating unsightly webbing around tree trunks and canopies. They feed on debris such as lichens, fungi, spores, and pollen (Hall 2019).

\section{CONTRIBUTING FACTORS}

Little is known about the factors that contribute to large psocid infestations. Live oak hammocks are the primary shelter for psocids during the winter months to protect them from frosts.

\section{MANAGEMENT RECOMMENDATIONS}

Because psocids are not harmful, management action is not recommended.

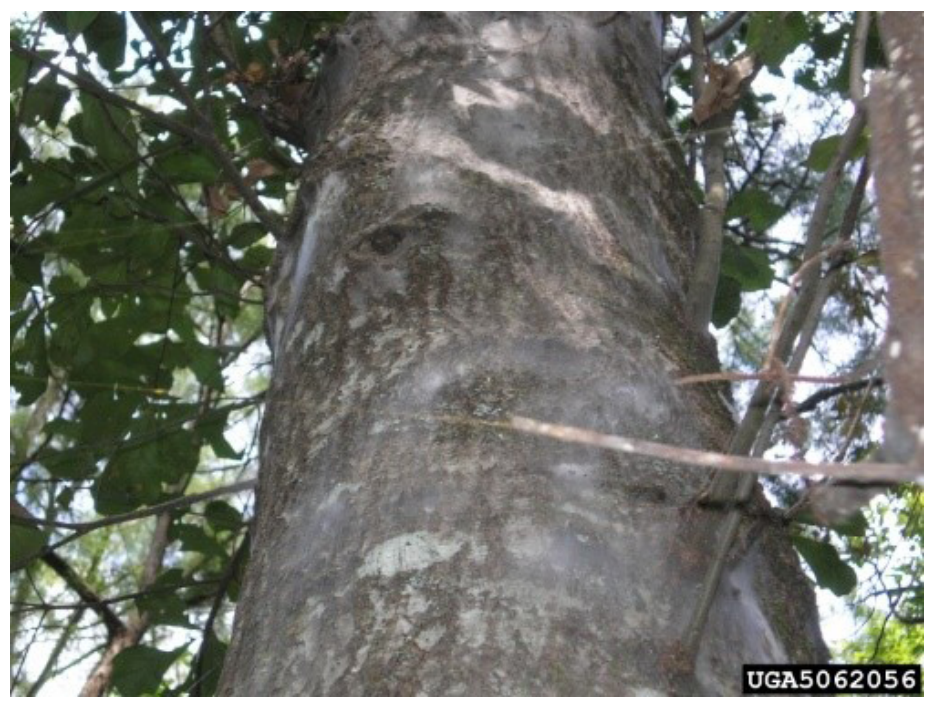

Figure 13. Webbing caused by psocids.

Credits: Mark McClure, Georgia Forestry Commission, Bugwood.org

\section{Lace Bugs}

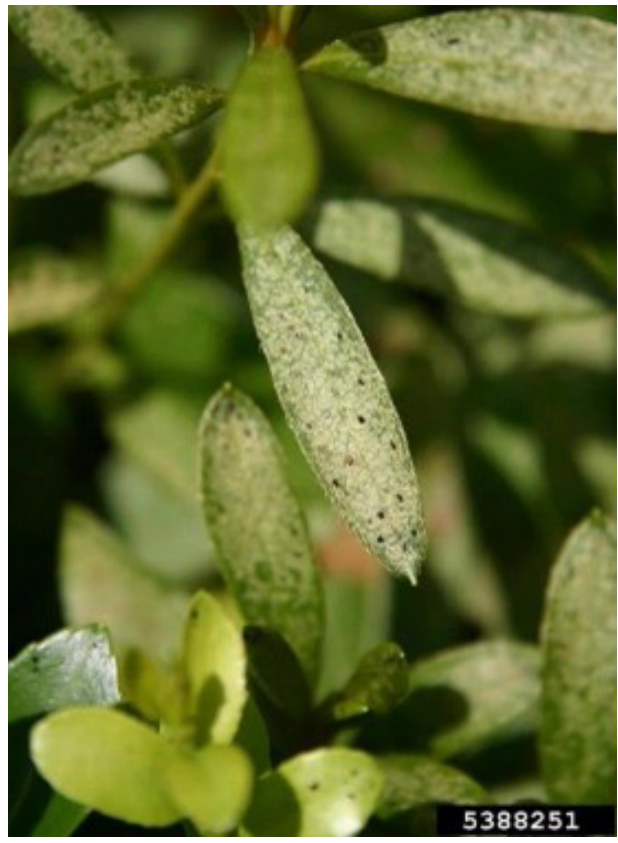

Figure 14. Lace bug damage on a leaf.

Credits: William Fountain, University of Kentucky, Bugwood.org

\section{RECOGNITION}

Oak lace bugs are sap-feeding insects that specialize on oaks, extract plant sap from the underside of leaves, and cause small white spots or stippling on the top of the leaf. The insects and their excrement (minute black droplets) are found almost exclusively on the underside of the leaf. Lace bug damage is often mistaken for mite damage. Although common, lace bug feeding rarely causes damage to large, 
established oak trees, and damage on landscape trees is primarily cosmetic (Rettke 2013).

\section{CONTRIBUTING FACTORS}

Oak lace bugs only feed on oaks, so outbreaks can be severe in some cases, particularly mass plantings of a single oak species and those in stressful urban conditions like full sun and drought.

\section{MANAGEMENT RECOMMENDATIONS}

Injury is mostly cosmetic, particularly on larger mature oaks, so it is rarely necessary to control oak lace bugs with insecticides. Natural enemies of the oak lace bugs include lady beetles and predatory mites, which may be used as a biological control through proper pesticide selection and use alongside augmentative releases (Rettke 2013).

\section{Woolly Oak Aphids (Stehophylla brevirostris)}

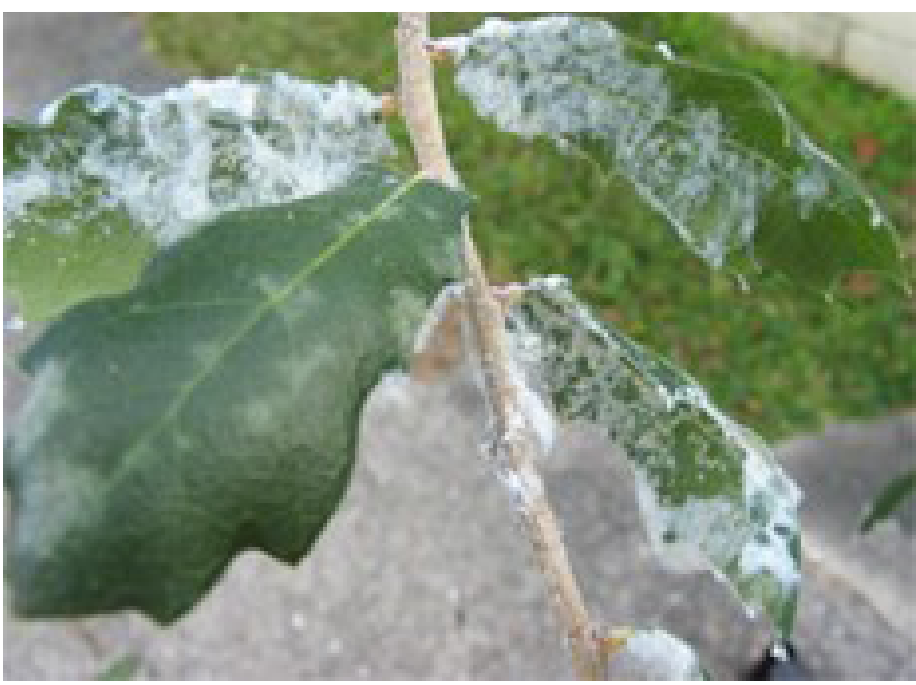

Figure 15. Stegophylla brevirostris Quednau colony on oak.

Credits: Susan E. Halbert, UF/IFAS

\section{RECOGNITION}

Woolly oak aphids are small, yellowish, piercing-sucking insects that cause leaf yellowing and distortion. Their white waxy secretions look like cottony fibers covering infested leaves and twigs. Under the woolly secretions adult aphids are translucent, while younger ones can be light green. Due to the white wax, they are sometimes mistaken for mealybugs or whiteflies.

\section{CONTRIBUTING FACTORS}

Little is known about the specific factors that cause woolly oak aphids to reach damaging levels on oaks. Observations suggest that stressful conditions like parking lot plantings surrounded by hardscape are associated with increased infestations.

\section{MANAGEMENT RECOMMENDATIONS}

Naturally occurring predators and parasites typically keep woolly oak aphids below damaging levels. However, this may not be enough in some cases. In most cases, woolly oak infestations do not require insecticides because their feeding does not cause significant damage. In severe cases, insecticidal soaps, horticultural oils, and systemic insecticides may be used for control (Halbert 2013).

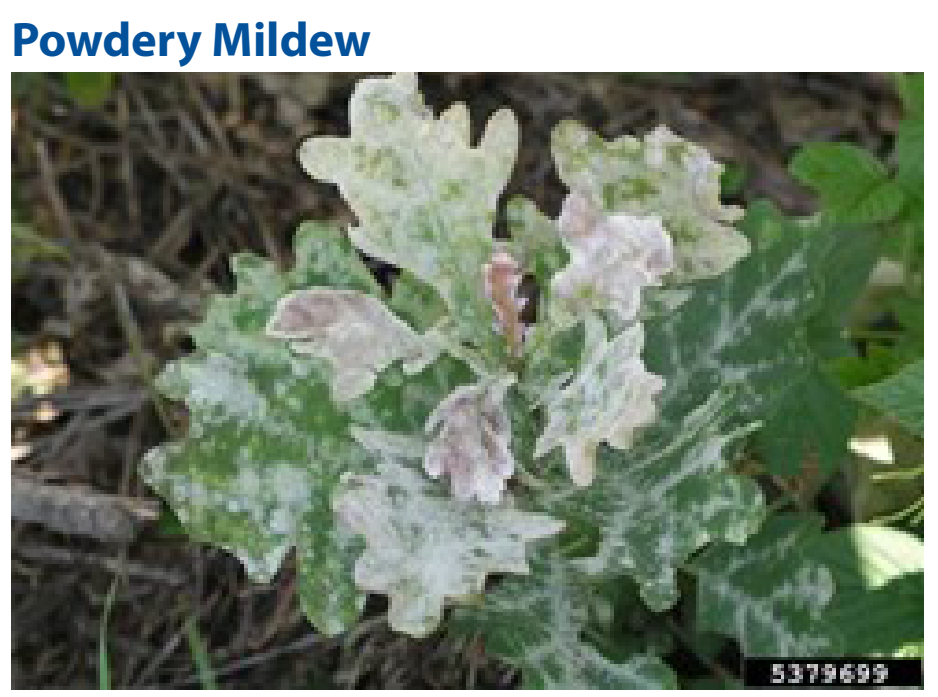

Figure 16. Powdery mildew on oak.

Credits: Andrej Kunca, National Forest Centre-Slovakia, Bugwood.org

\section{RECOGNITION}

Powdery mildew is caused by a fungus and occurs across many plant species. Initial signs are small white spots on top of the leaves. Spots then increase in size to fully cover leaves with powdery white growth. This results in deformed leaves and can cause leaves to die off in severe cases.

\section{CONTRIBUTING FACTORS}

Cool, moist conditions favor powdery mildew growth and spread.

\section{MANAGEMENT RECOMMENDATIONS}

Affected growth may be pruned out. Prevention is the best option by keeping plants in full sun and preventing moist conditions on the leaves to inhibit the fungus (UF/IFAS Gardening Solutions 2020).

\section{Spanish Moss, Ball Moss, and Lichens RECOGNITION}

Spanish moss, ball moss, and lichens are epiphytes, not parasites. They obtain nutrients from water and air and are not harmful to the tree. 
- Spanish moss (Tillandsia usneoides): This pale-green air plant is usually hanging in tree branches in long pendant strands.

- Ball moss (Tillandsia recurvata): This pale gray-green air plant grows in small tufts along the stem and branches.

- Lichens: Fungus and algae grow together in a mutually symbiotic relationship. Lichens grow in various forms, such as flat, hairlike, or leafy. The colors can be white, gray, red, green, yellow, or black.

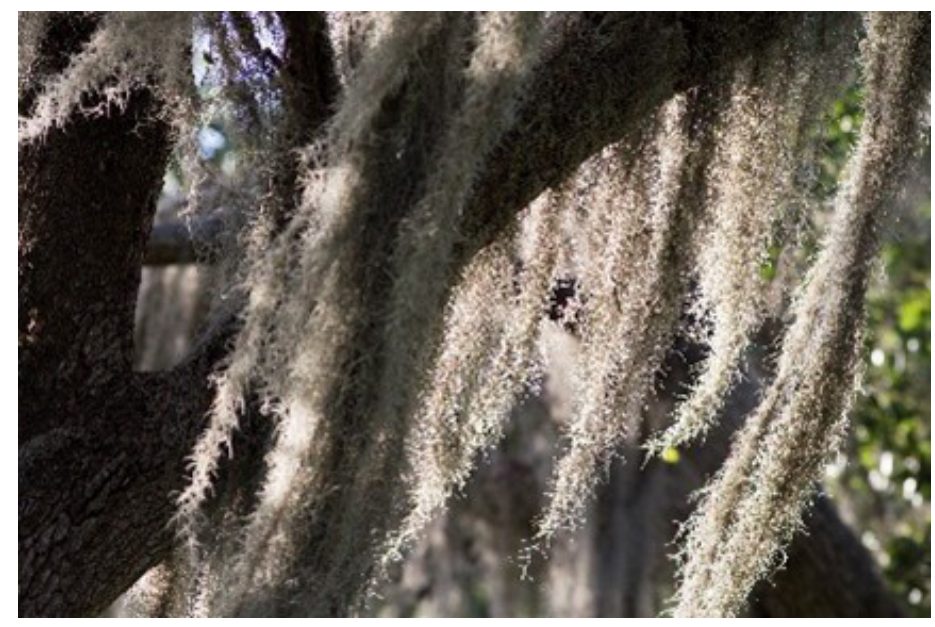

Figure 17. Spanish moss.

Credits: Tyler Jones, UF/IFAS

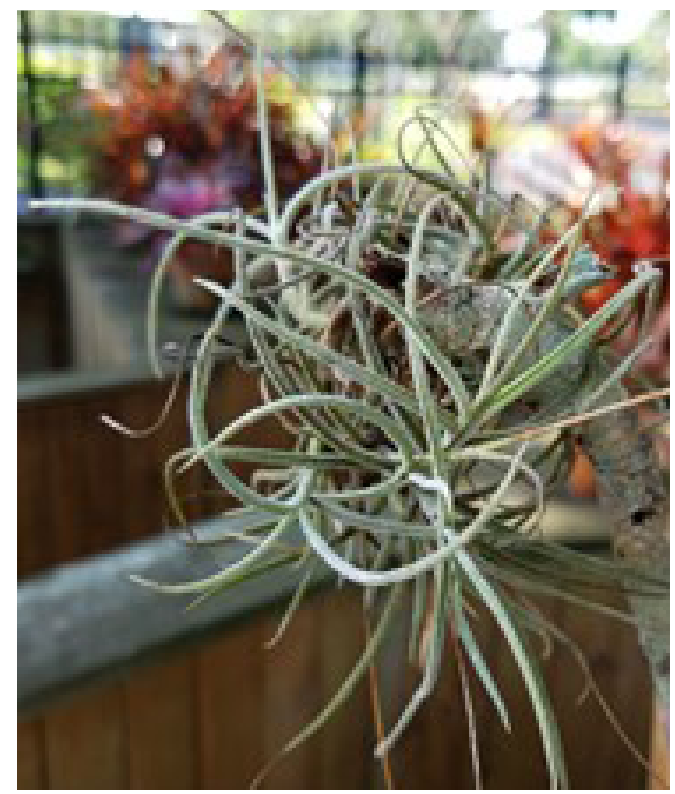

Figure 18. Ball moss.

Credits: Michelle Atkinson, UF/IFAS

\section{CONTRIBUTING FACTORS}

All prefer high-light areas and trees that are dying, have a thinning canopy, or have died. They do not harm healthy plants but may become thick enough to shade out interior branches.

\section{MANAGEMENT RECOMMENDATIONS}

In nursery settings, Spanish moss and ball moss should be removed from the tree to avoid reducing tree growth by shading. Copper sprays may be used to help kill the moss, but caution should be exercised to avoid damage to other plants, animals, aquatic life, and personal property. Manual removal is the most effective option. Otherwise, the best option is to leave them on the tree. Unnecessary action may ultimately harm the tree and surrounding areas. Visit Spanish Moss, Ball Moss, and Lichens for more management recommendations (Sewards and Brown 2013).

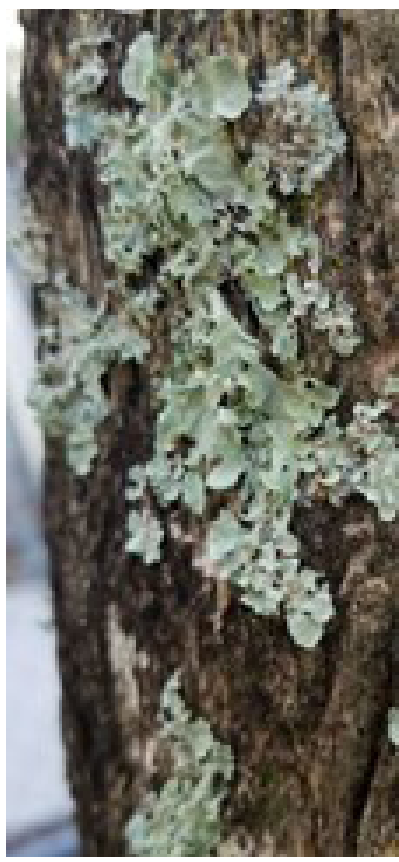

Figure 19. Lichen.

Credits: Michelle Atkinson, UF/IFAS

\section{References}

Frank, D. L., and R. F. Mizell III. 2006. Native and Exotic Insect Borers Are Important Crop Pests in the U.S. ENY-730. Gainesville: University of Florida Institute of Food and Agricultural Sciences. http://edis.ifas.ufl.edu/in640

Gilman, E. F., and D. G. Watson. 2014. Quercus virginiana: Southern Live Oak. ENH-722. Gainesville: University of Florida Institute of Food and Agricultural Sciences. http:// edis.ifas.ufl.edu/st564

Halbert, S. E. 2013. Woolly Oak Aphids. Gainesville: University of Florida Institute of Food and Agricultural Sciences. http://entnemdept.ufl.edu/creatures/TREES/ woolly_oak_aphid.htm

Hall, D. H. 2019. A Webbing Barklouse, A Psocid, Archipsocus nomas Gurney (Insecta: Psocoptera: Archipsocidae). EENY275. Gainesville: University of Florida Institute of 
Food and Agricultural Sciences. https://edis.ifas.ufl.edu/ in553

Perry, E. J., and C. L. Elmore. 2006. Mistletoe. IPM Education and Publications, University of California Statewide IPM Program. http://ipm.ucanr.edu/PMG/PESTNOTES/ pn7437.html

Rettke, S. E. 2013. “Oak Lace Bug Symptoms Have Bark, but They Have Little Bite.” Rutgers University. https:// plant-pest-advisory.rutgers.edu/oak-lace-bug-symptomshave-bark-but-they-have-little-bite/

Ruhl, G. E. 2018. "Tubakia Leaf Spot on Oak-a

Yearly Event.” Purdue Landscape Report, no. 18-16.

https://www.purduelandscapereport.org/article/

tubakia-leaf-spot-on-oak-a-yearly-event/

Sewards, J., and S. P. Brown. 2013. Spanish Moss, Ball Moss, and Lichens-Harmless Epiphytes. ENH1224. Gainesville: University of Florida Institute of Food and Agricultural

Sciences. https://edis.ifas.ufl.edu/ep485

Tovar-Sanchez, E. 2009. "Canopy Arthropod Community within and among Oak Species in Central Mexico." Current Zoology 55 (2): 132-144.

UF/IFAS Gardening Solutions. 2020. "Powdery Mildew." https://gardeningsolutions.ifas.ufl.edu/care/pests-anddiseases/diseases/powdery-mildew.html 